\title{
Effect of natural weathering on water absorption and pore size distribution in thermally modified wood determined by nuclear magnetic resonance
}

\author{
Chenyang Cai · Muhammad Asadullah Javed • Sanna Komulainen • \\ Ville-Veikko Telkki • Antti Haapala $\cdot$ Henrik Heräjärvi
}

Received: 3 December 2019/Accepted: 5 March 2020/Published online: 18 March 2020

(C) The Author(s) 2020

\begin{abstract}
Thermally modified wood (TMW) is widely used in outdoor applications due to its advanced properties towards weathering stresses. Although the structure changes of TMW from weather factors have been reported, investigation of the quantitative analysis of water states and cell wall structure of TMW after weathering is limited. In this work, the amount of bound water, fiber saturation point (FSP), cell wall pores, and free water distribution of thermally modified Scots pine, Norway spruce, and European ash were measured before and after a 2-year
\end{abstract}

C. Cai · A. Haapala

School of Forest Sciences, University of Eastern Finland, Joensuu, Finland

e-mail: chenyc@uef.fi

A. Haapala

e-mail: antti.haapala@uef.fi

M. A. Javed

Department of Chemical Engineering and Biotechnology, University of Cambridge, Cambridge, UK

e-mail: aj590@cam.ac.uk

S. Komulainen · V.-V. Telkki

NMR Research Unit, University of Oulu, Oulu, Finland e-mail: sanna.komulainen@oulu.fi

V.-V. Telkki

e-mail: ville-veikko.telkki@oulu.fi

H. Heräjärvi $(\bowtie)$

Natural Resources Institute Finland, Joensuu, Finland

e-mail: henrik.herajarvi@luke.fi natural weathering via NMR relaxometry, cryoporometry, and magnetic resonance imaging. The results show that weathering increased $\mathrm{T}_{2}$ relaxation time of lumens, indicating the degradation of tracheids and vessels, especially in TMW compared to unmodified wood. The amounts of bound water, FSP value, and cell wall pores were increased after weathering; however, an increase in thermal modification intensity resulted in lower FSP and limited the increase in number of pores. In summary, TMW showed better performance than unmodified wood after weathering.

Keywords Bound water - Free water - Fiber saturation point (FSP) $\cdot$ Cell wall pores $\cdot$ Nuclear magnetic resonance (NMR) · Thermally modified wood

\section{Introduction}

Thermal modification (TM) is an effective and chemical-free technology to improve dimensional stability and durability of wood, which are due to the reduced hygroscopicity (Esteves and Pereira 2009). Therefore, thermally modified wood (TMW) products are well suited to outdoor applications involving demanding weather conditions. As a green alternative to chemically modified wood and wood-plastic composites, TMW has become commercialized since the 1990s 
and is widely used in, for example, exterior decking, window frames, and cladding.

As a result of a weathering process, the extractives of wood are leached out and lignin becomes degraded, which makes the wood less water repellent and more hydrophilic (Williams 2005). Previous micrograph studies found that photodegradation occurs preferentially in the middle lamellae due to their higher lignin content. The lignin binding of microfibrils is degraded, resulting in cell wall checking and microcracks on pit borders transverse to the cell axis (Huang et al. 2012a). The mechanical properties of wood depend on its microstructure and moisture content below the fiber saturation point (FSP) (Kollmann and Côté 1968). Therefore, to understand the performance of TMW material after weathering, it is important to understand the wood-water interaction in cells and cell wall structures.

Different methods based on the nuclear magnetic resonance (NMR) of water can be applied to quantify the water content and porous microstructure of wood. NMR spectroscopy is an efficient and nondestructive method to study the wood-water relationship. Liquid confined to wood pores is subjected to interactions that change its NMR relaxation time. Thus, NMR relaxometry provides a detailed insight into liquid water in wood, whether as free molecules or bound to the cell wall. The $T_{2}$ relaxation times of liquid water depend on the mobility and local environment of its components (Brownstein and Tarr 1979). The moisture components with shorter relaxation times (a few milliseconds) are associated with bound water in cell walls, and the components with longer relaxation times (dozens to hundreds of milliseconds) are associated with free water in voids, such as cell lumens or bordered pits (Brownstein 1980; Menon et al. 1987; Flibotte et al. 1990; Labbé et al. 2006; Telkki et al. 2013).

The structure of cell wall pores relates to the physical (e.g., thermal conductivity) and mechanical (density, shrinkage and swelling) properties of wood and wood-based products (e.g., Zauer et al. 2013, Peng et al. 2015). Ding et al. (2008) stated that the features of cell wall pores may affect treatment processes, such as drying, chemical impregnation, and pulping. The porosity of cell walls varies greatly between species and within the trunk of an individual tree because of the inherently inhomogeneous cellular structure of wood (Yin et al. 2015). The International Union of
Pure and Applied Chemistry (IUPAC) classifies pores according to their size: (1) macropores have a diameter of more than $50 \mathrm{~nm}$ and are present in vessels, tracheids, rays, and pits; (2) mesopores and micropores, with pore sizes of $2-50 \mathrm{~nm}$ and $<2 \mathrm{~nm}$, respectively, occur between the cellulose microfibrils in the cell walls and are surrounded by lignin and hemicelluloses (Yin et al. 2015). The small diameter and variations in shape make analyzing the meso- and micropores difficult. However, according to Yin et al. (2015), these three classes of pores greatly influence the properties of wood material. NMR cryoporometry is a method to determine the pore size distributions of porous materials, by detecting the lowered solidliquid phased transition temperature of a substance confined to pores (Strange et al. 1993; Petrov and Furó 2009). According to the Gibbs-Thomson equation (Eq. 1) (Jackson and McKenna 1990), the melting point $\left(\Delta T_{m}\right)$ of a confined liquid is inversely proportional to pore radius $(\mathrm{r})$ :

$\Delta T_{\mathrm{m}}=T_{0}-T_{\mathrm{m}}=\frac{2 \sigma T_{0}}{r \Delta H_{f} \rho}=\frac{k}{r}$

where $T_{0}$ is the melting temperature of bulk liquid, $T_{\mathrm{m}}$ is the melting temperature in a cylindrical pore with a radius $r, \sigma$ is solid-liquid interface energy, $H_{\mathrm{f}}$ is the bulk enthalpy of fusion, and $\rho$ is the density of frozen water.

The melting point distribution is determined by measuring the amplitude of the liquid component as a function of temperature, and it can be converted to pore size distribution by Eq. 1. Thus, this method provides a convenient way to quantify the amount of liquid within the pores as a function of temperature and offers a quantitative and nondestructive method to determine the pore size distribution (Strange et al. 1993; Aksnes and Kimtys 2004).

Magnetic resonance imaging (MRI) provides temporally and spatially resolved moisture profiles. The intensity of the MRI signal is proportional to the number of hydrogen nuclei in the samples (Menon et al. 1989).

NMR techniques have proven an excellent tool to determine the distribution and concentration of water in wood (Bucur 2003). An important advantage of NMR over other methods (i.e., X-ray computer tomography) is its ability to distinguish between bound and free water by relaxation analysis (Riggin 
et al. 1979). In addition, NMR provides quantity information about pore size distribution in wood (Kekkonen et al. 2014). NMR is suitable for wet wood; dry wood porosity could be measured with other methods, such as nitrogen adsorption pycnometry (Yin et al. 2015), mercury intrusion porosimetry (Peng et al. 2015), or X-ray $\mu \mathrm{CT}$ (Peng et al. 2015).

Although the moisture effects, dynamics, and porosity of wood have been extensively studied by numerous experimental methods (e.g., Stone 1964; Roles et al. 2001; Park et al. 2006; Almeida et al. 2007; Nakatani et al. 2008; Borrega and Kärenlampi 2011; Meng et al. 2013; Zauer et al. 2013, 2014; Peng et al. 2015), the states of water and pore size distribution affected by TM and natural weathering have not been studied comprehensively. Our aim was to quantify the effect of natural weathering on the moisture distribution, fiber saturation point, and pore size distribution in the cell wall structure of thermally modified Scots pine, Norway spruce, and European ash by several NMR techniques, including NMR relaxometry, NMR cryoporometry, and MRI.

\section{Materials and methods}

\section{Materials}

Scots pine (Pinus sylvestris), Norway spruce (Picea abies), and European ash (Fraxinus excelsior) planks of $130 \mathrm{~mm} \quad$ (tangential) $\times 32 \mathrm{~mm}$ (radial) $\times 4000 \mathrm{~mm}$ (longitudinal) were kiln dried at $60{ }^{\circ} \mathrm{C}$ for 2 weeks and thermally modified into two grades (Thermo $\mathrm{S}$ and D) using the ThermoWood ${ }^{\circledR}$ process with the presence of steam (Viitaniemi et al. 1997) by HJT-Holz Ltd., in Vilppula, Finland. In Thermo S modification, pine and spruce wood planks were modified at $180{ }^{\circ} \mathrm{C}$ for $2 \mathrm{~h}$ and ash at $190{ }^{\circ} \mathrm{C}$ for $2.5 \mathrm{~h}$. In Thermo D treatment, pine and spruce wood planks were modified at $212{ }^{\circ} \mathrm{C}$ for $3 \mathrm{~h}$ and ash at $200{ }^{\circ} \mathrm{C}$ for $2.5 \mathrm{~h}$. Unmodified boards from the same species served as controls.

Natural weathering

Natural weathering of TMW and control boards was performed in Joensuu, Finland $\left(62^{\circ} 36^{\prime} 6^{\prime \prime}\right.$ latitude, $29^{\circ} 43^{\prime} 26^{\prime \prime}$ longitude) for 2 years, from November 2016 to October 2018. Boards were set outside without any cover from the relevant factors, such as sun, rain, snow, and wind. To imitate the wet and dry end-use conditions of typical decking material, boards were aligned parallel to the ground in a $30 \mathrm{~mm}$ deep pool, so that they were occasionally immersed by rainwater or snow and ice. Boards did not have direct contact with the pool, but they were fixed on a metal net that was attached to the bottom of the pool. Table 1 shows the meteorological data for Joensuu during the weathering period.

Sample preparation

Cylindrical samples (axis along the radial direction) with a diameter of $6 \mathrm{~mm}$ and length of $20 \mathrm{~mm}$ were cut from the interior of both the TMW and the unmodified boards before and after natural weathering. Each wood sample contained 6-13 annual rings (Fig. 1).

Prior to the NMR measurements, the wood samples were immersed in distilled water at room temperature for 1 month to achieve full cell wall saturation. The extra water from the surface of the wood samples was removed before weighting and inserting them, one at a time, into a $10 \mathrm{~mm}$ medium wall NMR tube with an inner diameter of $8 \mathrm{~mm}$. To avoid moisture evaporation, the NMR tube was immediately closed with a plastic cap.

Five replicates were prepared from each heat treatment group for NMR relaxometry, and one of the former five samples was randomly chosen for NMR cryoporometry and MRI.

\section{${ }^{1} \mathrm{H} N \mathrm{NR}$ relaxometry and cryoporometry}

${ }^{1} \mathrm{H}$ NMR measurements were carried out on a Bruker Avance III 300 spectrometer with a magnetic field strength of $7.1 \mathrm{~T}$ using a $10 \mathrm{~mm}$ BBFO probe. In both relaxometry and cryoporometry experiments, spectra were measured using a single-scan CPMG (CarrPurcell-Meiboom-Gill) pulse sequence with an echo time of $0.5 \mathrm{~ms}$ and 1024 echoes. There were 64 scans, and the experiment lasted approximately $2 \mathrm{~min}$. The length of the $90^{\circ}$ pulse was $26.5 \mu \mathrm{s}$, and the relaxation delay was $1.5 \mathrm{~s}$.

For relaxometry measurements, spectra were measured at 295 and $263 \mathrm{~K}$. The relaxation time distributions of water in various wood samples were determined by performing the Laplace inversion of 
Table 1 Joensuu meteorological data (source: Finnish Meteorological Institute)

\begin{tabular}{lc}
\hline Climatic parameters (monthly average) & Nov. 2016-Oct. 2018 \\
\hline Precipitation $(\mathrm{mm})$ & 53.7 \\
Temperature $\left({ }^{\circ} \mathrm{C}\right)$ & 7.0 \\
Max temperature $\left({ }^{\circ} \mathrm{C}\right)$ & 19.7 \\
Min temperature $\left({ }^{\circ} \mathrm{C}\right)$ & 11.2 \\
Relative humidity $(\%)$ & 76.2 \\
Cloud amount $(1 / 8)$ & 5.2 \\
Global radiation $\left(\mathrm{W} / \mathrm{m}^{2}\right)$ & 118.9 \\
Long wave solar radiation $\left(\mathrm{W} / \mathrm{m}^{2}\right)$ & 313.8 \\
Ultraviolet irradiance $($ index $)$ & 0.5 \\
\hline
\end{tabular}

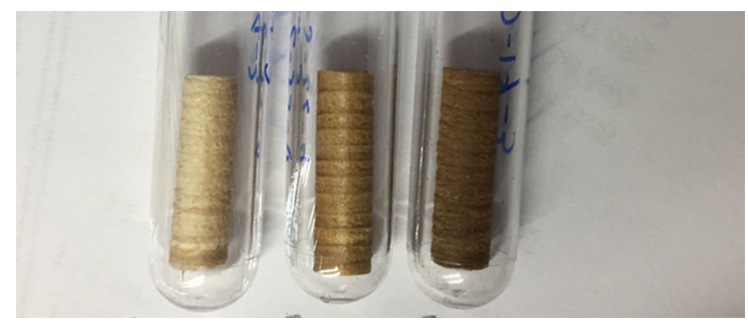

Fig. 1 NMR sample preparation

the CPMG data. The inverse Laplace transform is an ill-posed problem, but it becomes feasible with the use of regulators and constraints (Song et al. 2002). Nonnegative constraint along with the Tikhonov regularization based on $l_{2}$ were used to stabilize the inversion (Provencher 1982). The regulator favors smooth and sparse relaxation time or diffusion coefficient distributions over spiky distributions. The minimum and maximum values of the $T_{2}$ distributions was set to be $0.1 \mathrm{~ms}$ and $10 \mathrm{~s}$, covering well the whole range of relaxation times observable in the CPMG experiments, in which the data point was probed from 0.5 to $512 \mathrm{~ms}$. The number of points in the resulting $T_{2}$ distributions is 256 and the step between successive points is logarithmically increasing.

For cryoporometry analysis, CPMG data were measured at variable temperatures from 194 to $290 \mathrm{~K}$, with a step of $2.6 \mathrm{~K}$. The temperature stabilization delay was approximately one hour before the first experiment (i.e., at $194 \mathrm{~K}$ ) and about $15 \mathrm{~min}$ in the following temperature steps (Kekkonen et al. 2014). Therefore, the temperature raised about $10 \mathrm{~K} /$ $\mathrm{h}$, which is slow enough rate to keep the sample at thermal equilibrium (Petrov and Furó 2009). The amplitude of the first echo (an echo time $0.5 \mathrm{~ms}$, much longer than the $T_{2}$ of ice, $\sim 10 \mu \mathrm{s}$ ) was assumed to be proportional to the amount of unfrozen water and used to determine pore size distribution. To avoid the temperature dependence of thermal equilibrium magnetization defined by the Curie law, the intensities of signals as a function of temperature were corrected by multiplying with a factor $T / T_{0}$ (Kekkonen et al. 2014), where $T$ is the temperature at which one particular CPMG experiment was performed and $T_{0}$ is the maximum temperature of the CPMG. This correction rendered the intensities of the signals proportional to the true amount of unfrozen water. The pore size distribution in the wood samples was determined by a least-squares fit of a model function to the integrals, as described by Aksnes et al. (2001). Constant $k$ in Eq. 1 was taken to be $30 \mathrm{~nm} \mathrm{~K}$, the value experimentally determined for water absorbed in controlled pore glasses (Petrov and Furó 2006). Hansen et al. (1996) explained the presence of a non-freezing layer with a thickness of about $0.3-0.8 \mathrm{~nm}$; therefore, to determine the true pore size of the wood samples, the average value of $0.6 \mathrm{~nm}$ was added to the calculated diameter values.

\section{Magnetic resonance imaging}

The wood samples were wrapped by Parafilm and fixed by Teflon spacers inside the NMR tube to prevent rotation due to vibrations caused by the gradients. ${ }^{1} \mathrm{H}$ MRI experiments were carried out on a Bruker Avance DSX300 spectrometer (Billerica, MA, USA) for unweathered samples; after weathering, experiments were performed on a Bruker Avance III 300 spectrometer. Both spectrometers were equipped with Micro2.5 micro-imaging units with $\mathrm{x}, \mathrm{y}$, and $\mathrm{z}$ gradients. The MRI measurements were carried out with a $10 \mathrm{~mm}{ }^{1} \mathrm{H}$ radio frequency (RF) insert and 
Paravision software. The position and orientation of the wood sample was adjusted with the help of gradient echo pulse sequence by acquiring the images in three orthogonal directions. The sagittal (radialtangential direction) images were acquired via a spinecho imaging pulse sequence. For unweathered and weathered samples, a $2 \mathrm{~mm}$ thick slice was measured with field of view (FOV) of $25 \mathrm{~mm}$ and $30 \mathrm{~mm}$ in the read direction and $9 \mathrm{~mm}$ in the phase direction. The matrix sizes were 25 or $30 \mathrm{~mm} \times 9 \mathrm{~mm}$ with a resolution of $100 \mu \mathrm{m}$ per pixel in both directions. The echo time was $13.8 \mathrm{~ms}$, repetition time $1.1 \mathrm{~s}$, and experiment time approximately $6 \mathrm{~min}$ with four scans. The images were analyzed by MATLAB-based code.

\section{Fiber saturation point}

After the NMR experiments, all the specimens were oven dried at $105^{\circ} \mathrm{C}$ for $24 \mathrm{~h}$, and the moisture content (MC) of the individual specimens was determined based on the oven dry mass and mass after 1month water immersion. The FSP, which denoted the maximum amount of water adsorbed by cell walls, can be calculated by (Telkki et al. 2013)

$\operatorname{FSP}(\%)=\operatorname{MC} \times\left(S_{b}-S_{t}\right)$,

where $S_{b}$ is the integral of the bound water peak and $S_{t}$ is the total integral of the moisture peaks in the relaxation time distribution.

\section{Results and discussion}

Environments of bound and free water

The $T_{2}$ relaxation time distributions of one representative specimen from each group measured at $263 \mathrm{~K}$ and $295 \mathrm{~K}$ are shown in Fig. 2. The other four samples within the same groups repeated similar patterns, confirming the results. When the temperature is below the melting point of bulk water, free water freezes and its signal disappears. Therefore, the remaining $\mathrm{T}_{2}$ peak at $263 \mathrm{~K}$ resulted from bound water in the cell wall (Telkki et al. 2013; Fredriksson and Thygesen 2017). For pine and spruce, the $\mathrm{T}_{2} \leq 1 \mathrm{~ms}$ did not vary much due to TM or weathering. For unmodified ash, the $\mathrm{T}_{2}$ appeared around 2-3 ms, which is in agreement with previous studies (Gao et al. 2015; Gezici-Koç et al. 2017). The $T_{2}$ value became shorter after TM (Thermo
$\mathrm{S}: 1.5 \mathrm{~ms}$, Thermo D: $1.1 \mathrm{~ms})$ due to the decreased mobility of water molecules in the cell walls (GeziciKoç et al. 2017). However, weathering did not change the $\mathrm{T}_{2}$ of bound water.

Several $\mathrm{T}_{2}$ peaks were observed at $295 \mathrm{~K}$. The shortest (peak 1) corresponds to the bound water signal observed at $263 \mathrm{~K}$, while the other peaks arose from the free water. The $\mathrm{T}_{2}$ of water in porous media could be considered approximately proportional to the pore diameter (Gao et al. 2015).

For unmodified pine and spruce, peak 2 was previously assigned to lumen water in tracheid cells of latewood and ray lumens, while peak 3 was attributed to earlywood tracheid lumens (Kekkonen et al. 2014; Gao et al. 2015; Gezici-Koç et al. 2017). However, Fredriksson and Thygesen (2017) studied the states of water in earlywood and latewood separately and concluded that peak 3 represents lumen water in tracheid cells, while peak 2 corresponds to the volume of smaller voids (e.g., ray cell lumens, pits, and tracheid lumen ends). In previous studies, a $\mathrm{T}_{2}$ value observed in a similar range as the $T_{2}$ for peak 4 in the present study was assigned to organic components (Labbé et al. 2006) and surface water on the specimens (Fredriksson and Thygesen 2017). After TM, peak 4 disappeared and the $T_{2}$ of peaks 2 and 3 increased, indicating the removal of extractives and resin (Javed et al. 2015), an increase in lumen volume by microcracking in cell walls (Andersson et al. 2005; Cai et al. 2018), and deformation and merging in earlywood tracheids (Welzbacher et al. 2011). The relative significance of these factors could not be assessed. Similar to the effect of TM, 2-year natural weathering also increased the $\mathrm{T}_{2}$ values of peaks 2 and 3 due to degradation of middle lamellar, cell wall checking, and destruction of bordered pits (Huang et al. 2012a). More obvious changes occurred in thermally modified samples than in unmodified controls.

For unmodified ash, the distribution at $295 \mathrm{~K}$ contained three peaks, which were considered to arise from bound water in cell walls (peak 1) and free water in lumens of fibers and parenchyma (peak 5) and vessels (peak 6, Almeida et al. 2007; Gao et al. 2015). However, peak 5 split into 3 and 2 peaks after Thermo $\mathrm{S}$ and Thermo D modifications, probably due to the socalled pearling artefact arising from the Laplace inversion (Telkki 2018). This might also imply that the exchange between free water in different sizes and 

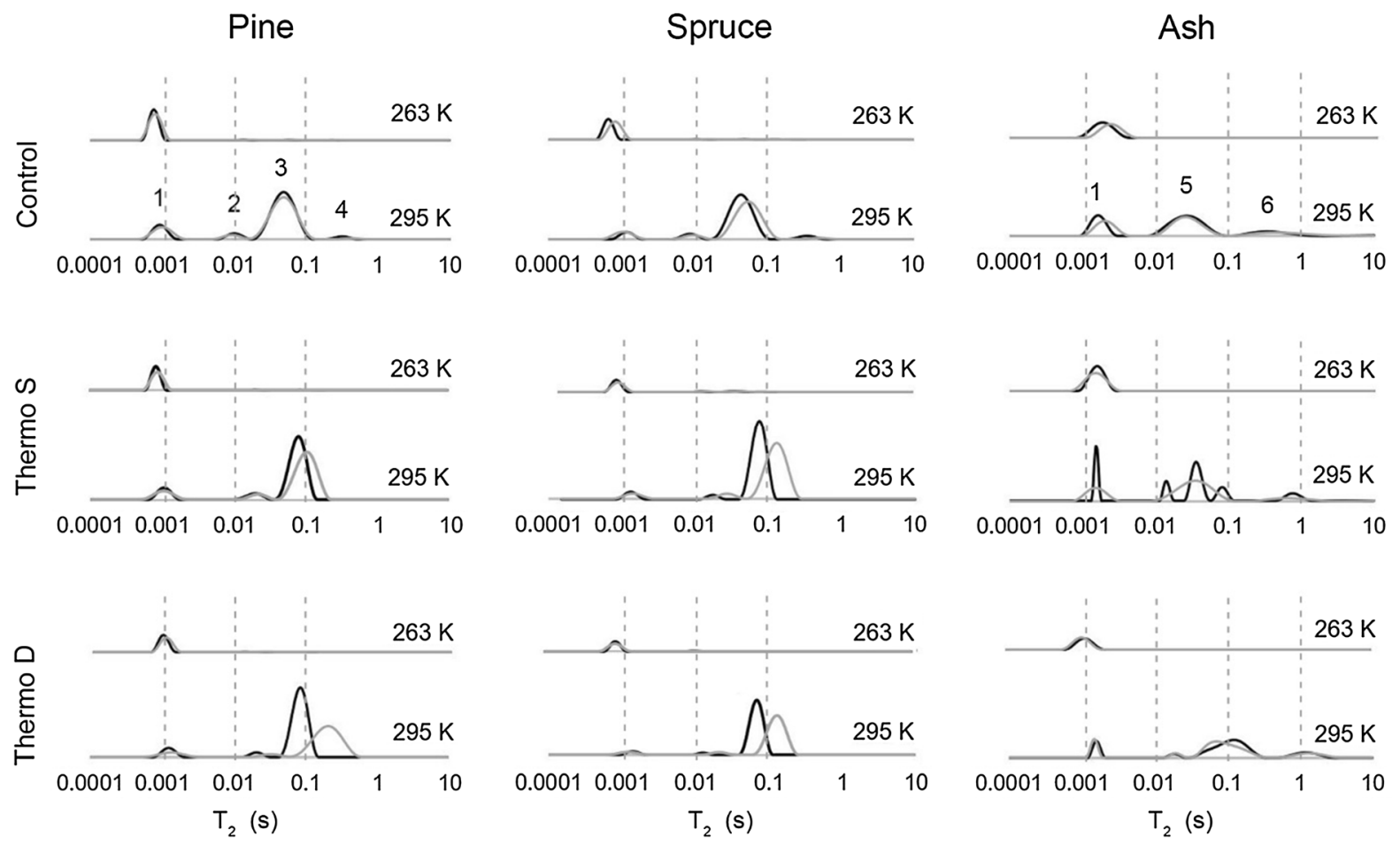

Fig. $2 \mathrm{~T}_{2}$ relaxation time distributions of samples at $263 \mathrm{~K}$ and $295 \mathrm{~K}$ before (black) and after (grey) 2-year natural weathering, measured by NMR relaxometry

positions of fiber is slow. Similar to pine and spruce, except for the bound water peak, the remaining peaks shifted to a longer $\mathrm{T}_{2}$ after $\mathrm{TM}$, probably also indicating the collapse of the earlywood cell wall and merging in vessels (Welzbacher et al. 2011). In contrast to the softwood, Thermo-S-modified samples showed no effect on the $T_{2}$ values and only a decreased number of peaks, probably implying a faster free water exchange in fibers after weathering.

Amounts of water components and FSP value

The relative amounts of bound and free water in samples were determined by the peak integrals at $263 \mathrm{~K}$ and $295 \mathrm{~K}$ from Fig. 2, and the FSP value can be calculated by Eq. 2. Table 2 shows the FSP and amounts of bound, free, and total water before and after weathering.

The reduced amount of bound water of all modified species implied that wood becomes more hydrophobic after TM due to the partial elimination of the hydrophilic hydroxyl groups of hemicelluloses (Altgen et al. 2016). In addition, the increase in modification intensity (from Thermo $\mathrm{S}$ to Thermo D) reduced the amount of bound water, which is in agreement with previous research (Kekkonen et al. 2014). Although the total amount of absorbed water decreased gradually with the more severe modification treatments, the amount of free water did not change similarly. For example, modified ash had higher free water content than its unmodified control, while pine had the opposite result.

FSP is defined as the MC corresponding to the amount of water contained within the saturated cell wall (Stone and Scallan 1967). However, wood exhibits sorption hysteresis; the MC of wood is higher if it is reached by desorption than by absorption under the same ambient conditions. The explanations of the hysteresis for capillary water condensed in lumens and pits suggested in literature are "ink bottle" theory and the effect of contact angle between absorbed water and the internal surface of the wood material (Chen and Wangaard 1968; Engelund et al. 2013). The suggested mechanisms behind the hysteresis in cell wall are relating to the mechanical response of cell walls and hydrogen bonding configurations as the moisture 
Table 2 The average moisture component content (a.u.) (bw: bound water, fw: free water, tw: total water) and the fiber saturation point (FSP) before and after 2-year natural weathering. The values are averages over five replicate samples, and the errors were calculated based on variations between the replicates

\begin{tabular}{|c|c|c|c|c|c|c|c|c|}
\hline \multirow[t]{2}{*}{ Treatments } & \multicolumn{4}{|c|}{ Before weathering } & \multicolumn{4}{|c|}{ After weathering } \\
\hline & bw & $\mathrm{fw}$ & $\mathrm{tw}$ & FSP $(\%)$ & bw & fw & tw & FSP (\%) \\
\hline \multicolumn{9}{|l|}{ Pine } \\
\hline Control & $2.19 \pm 0.10$ & $8.91 \pm 0.45$ & $11.10 \pm 0.43$ & $38.6 \pm 0.9$ & $2.19 \pm 0.19$ & $8.96 \pm 0.17$ & $11.16 \pm 0.19$ & $40.4 \pm 0.5$ \\
\hline Thermo S & $1.70 \pm 0.14$ & $8.75 \pm 0.45$ & $10.45 \pm 0.42$ & $30.7 \pm 1.2$ & $1.72 \pm 0.2$ & $8.76 \pm 0.16$ & $10.48 \pm 0.27$ & $34.6 \pm 3.4$ \\
\hline Thermo D & $1.23 \pm 0.07$ & $8.59 \pm 0.60$ & $9.82 \pm 0.62$ & $24.2 \pm 1.4$ & $1.32 \pm 0.21$ & $7.97 \pm 0.12$ & $9.28 \pm 0.14$ & $29.9 \pm 2.0$ \\
\hline \multicolumn{9}{|l|}{ Spruce } \\
\hline Control & $1.95 \pm 0.16$ & $8.37 \pm 0.86$ & $10.32 \pm 0.74$ & $37.7 \pm 1.7$ & $2.10 \pm 0.31$ & $8.70 \pm 0.28$ & $10.81 \pm 0.33$ & $40.7 \pm 2.0$ \\
\hline Thermo S & $1.50 \pm 0.41$ & $8.95 \pm 0.72$ & $10.46 \pm 1.09$ & $31.3 \pm 3.4$ & $1.32 \pm 0.27$ & $8.91 \pm 0.77$ & $10.23 \pm 0.97$ & $30.7 \pm 2.0$ \\
\hline Thermo D & $1.09 \pm 0.19$ & $8.22 \pm 0.93$ & $9.31 \pm 1.02$ & $24.3 \pm 3.0$ & $1.14 \pm 0.19$ & $8.59 \pm 0.15$ & $9.74 \pm 0.16$ & $27.3 \pm 1.6$ \\
\hline \multicolumn{9}{|l|}{ Ash } \\
\hline Control & $3.52 \pm 0.31$ & $4.52 \pm 0.40$ & $8.05 \pm 0.51$ & $47.7 \pm 1.2$ & $3.55 \pm 0.18$ & $4.62 \pm 0.55$ & $8.17 \pm 0.57$ & $50.6 \pm 2.6$ \\
\hline Thermo S & $2.41 \pm 0.30$ & $4.55 \pm 0.62$ & $6.96 \pm 0.56$ & $37.8 \pm 3.9$ & $2.48 \pm 0.23$ & $4.76 \pm 0.56$ & $7.24 \pm 0.68$ & $39.4 \pm 3.4$ \\
\hline Thermo D & $1.32 \pm 0.42$ & $4.85 \pm 0.59$ & $6.18 \pm 0.47$ & $22.6 \pm 0.9$ & $1.38 \pm 0.21$ & $4.87 \pm 0.48$ & $6.24 \pm 0.46$ & $24.5 \pm 1.5$ \\
\hline
\end{tabular}

induced dimensions change (Engelund et al. 2013; Chen et al. 2018; Fredriksson and Thybring 2019). Zauer et al. (2014) states that the FSP value measured from water saturated wood is higher than the generally assumed FSP of $30 \%$, because the swollen cell wall provides higher availability of bonding sites of sorption on molecular surfaces. Fredriksson and Thybring (2019) reported that cell walls are not water-saturated before the whole piece of wood is fully water-saturated. Furthermore, there is an uncertainty that the cell wall may not be fully saturated without applying vacuum impregnation. However, the diameter of specimens in our study was $6 \mathrm{~mm}$, which means the maximum absorption distance in longitudinal direction is $3 \mathrm{~mm}$. The length of a tracheid cell is normally 2-3 $\mathrm{mm}$ in Scots pine and Norway spruce (Mäkinen et al. 2008), and the length of fiber is approximately $1 \mathrm{~mm}$ in European ash (Koddenberg and Militz 2018). Therefore, the maximum distance of water migration is 1-3 cells. We assume that the specimens achieved full water saturation after 1-month immersion in distilled water.

The results show that FSP values of unmodified pine and spruce without weathering were $39 \% \pm 1 \%$ and $38 \% \pm 2 \%$, respectively, which are close to the values measured by solute exclusion or NMR methods in previous studies (e.g., Hill et al. 2005; Telkki et al.
2013; Gao et al. 2015). On the other hand, the FSP value of unmodified ash before weathering was $48 \% \pm 2 \%$, which is clearly higher than the values of $34.6 \%$ reported by Gao et al. (2015) from NMR and $38.6 \%$ reported by Zauer et al. (2014) from differential scanning calorimetry (DSC). The great difference can be at least partly explained by the variation between samples (i.e., material origin), but other factors may also be involved.

In accordance with previous results by Zauer et al. (2014), all species showed a significant reduction in FSP due to thermal modification; this reduction is mainly caused by the irreversible degradation of hydrophilic hemicelluloses. The chemical changes in lignin and the crosslinking reactions of organic acids and phenol units of lignin also play a role in FSP reduction (Tjeerdsma and Militz 2005; Zauer et al. 2014).

A slight increase in FSP was observed after weathering in all samples except the Thermo-Smodified spruce. The reasons for this phenomenon might be related to reducing or removing the water repellent effect of extractives (Kalnins and Feist 1993), degrading the hydrophobic lignin components (Tomak et al. 2018), and allowing easier entrance of water into the cell wall due to microcrack formation (Huang et al. 2012b). The increased hygroscopicity 
and cell wall degradation of weathered wood is suggested as a contributing factor for this increase in FSP. Although the amount of absorbed water and FSP value increased due to weathering, the decreasing trend from unmodified controls to Thermo-S- and Thermo-D-modified samples indicated that TM can still restrict water absorption after 2 years of weathering.

Pore size distribution of the cell walls

The liquid water amount was measured as a function of temperature from 194 to $290 \mathrm{~K}$, from which the pore size distribution can be calculated using the Gibbs-Thomson equation (Eq. 1). Figure 3 shows the results. Below $273 \mathrm{~K}$, free water in the cell lumen freezes, and the subsequent signal arises from bound water in the cell wall.

The TM process decreased the bound water amount for all species, and a higher modification temperature led to less bound water in cell walls due to the reduced hygroscopicity caused by TM (Esteves and Pereira 2009). This finding is consistent with the results shown in Table 2. After natural weathering, the majority of the softwood specimens showed a slight increase in bound water along the temperature range (except the Thermo-S-modified spruce). The weathered ash specimens showed a lower amount and eventually a slightly higher amount of bound water content than unweathered ash after ca. $250 \mathrm{~K}$.

Figure 3 and Table 3 show that the meso$(2-50 \mathrm{~nm})$ and micropore $(<2 \mathrm{~nm})$ size distribution
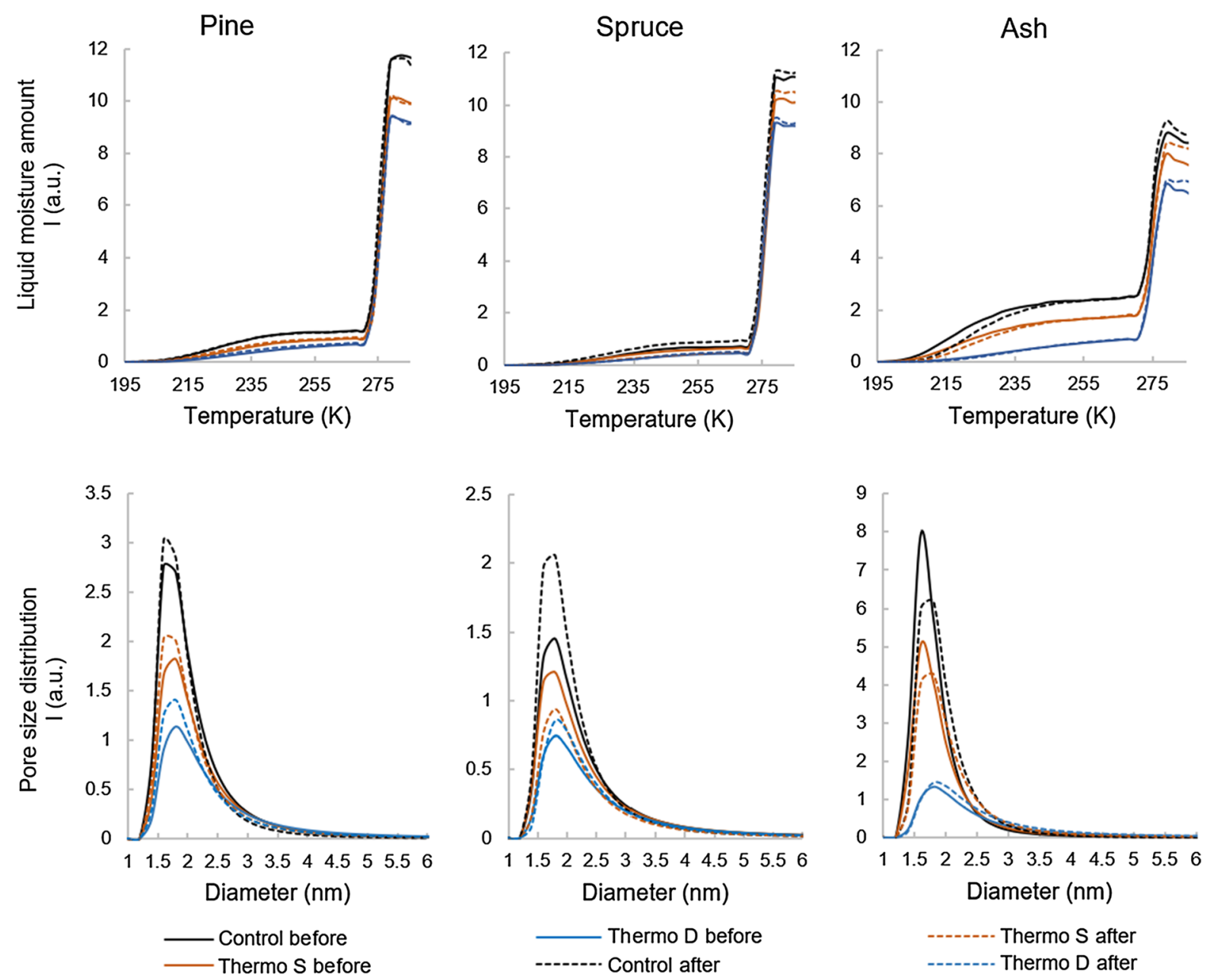

Fig. 3 The liquid moisture amount within samples as a function of temperature and the pore size distribution of cell walls, measured by NMR cryoporometry 
Table 3 The area (integral) of pore size distribution of saturated cell wall before and after 2-year natural weathering (a.u.; values in parentheses represent pore proportion: \%)

\begin{tabular}{|c|c|c|c|c|c|c|c|c|c|}
\hline \multirow[t]{2}{*}{ Size (nm) } & \multicolumn{3}{|l|}{ Pine } & \multicolumn{3}{|l|}{ Spruce } & \multicolumn{3}{|l|}{ Ash } \\
\hline & Control & Thermo S & Thermo D & Control & Thermo S & Thermo D & Control & Thermo S & Thermo D \\
\hline \multicolumn{10}{|l|}{ Before } \\
\hline$<2.5$ & $9.8(82.5)$ & $7.0(76.5)$ & $4.5(67.7)$ & 5.7 (73.6) & 4.9 (71.2) & $3.1(62.7)$ & $21.8(94.0)$ & $15.7(89.5)$ & $5.3(67.1)$ \\
\hline$>2.5$ & $2.1(17.5)$ & $2.1(23.5)$ & $2.2(32.3)$ & $2.0(26.4)$ & $2.1(28.8)$ & $1.9(37.3)$ & $1.4(6.0)$ & $1.9(10.5)$ & $2.6(32.9)$ \\
\hline Total & 11.9 & 9.1 & 6.7 & 7.7 & 7.0 & 5.0 & 23.2 & 17.6 & 7.9 \\
\hline \multicolumn{10}{|l|}{ After } \\
\hline$<2.5$ & $10.4(87.9)$ & 7.7 (81.5) & $5.4(75.9)$ & 7.6 (81.6) & 3.7 (70.6) & $3.4(66.4)$ & $20.8(89.2)$ & $15.3(84.2)$ & $5.9(62.4)$ \\
\hline$>2.5$ & $1.5(12.1)$ & $1.7(18.5)$ & $1.7(24.1)$ & 1.7 (18.4) & $1.5(29.4)$ & 1.7 (33.6) & $2.6(10.8)$ & $2.9(15.8)$ & $3.6(37.7)$ \\
\hline Total & 11.9 & 9.4 & 7.1 & 9.3 & 5.2 & 5.1 & 23.4 & 18.2 & 9.5 \\
\hline
\end{tabular}

in cell walls changed after TM and weathering. The distribution implied that the pores in cell walls are between 1.2 and $5 \mathrm{~nm}$ in diameter. This finding is in agreement with Hill (2006) and Kekkonen et al. (2014), who reported that the maximum size of cell wall pores is $2-4 \mathrm{~nm}$ by the solute exclusion method and $1.5-4.5 \mathrm{~nm}$ by the cryoporometry method. Consistent with previous studies (Zauer et al. 2013; Kekkonen et al. 2014), the amount of meso- and micropores decreased considerably due to TM and decreased further with the increasing modification intensity. This result indicates a reduced interfibrillar and intermicellar space, which may be caused by shrinkage of the cell wall (Zauer et al. 2013), increase in cellulose crystallinity and the size of cellulose crystallites (Andersson et al. 2005), reduced swelling behavior of the cell wall (Esteves et al. 2007), or softening and flow of lignin to fill in the cell wall pores (Zauer et al. 2014).

More than $90 \%$ of the pores present in cell walls had a diameter of less than $4.5 \mathrm{~nm}$, and $60-80 \%$ of these were smaller than $2.5 \mathrm{~nm}$ (Table 3), which is in accordance with the findings by Gao et al. (2015). Kekkonen et al. (2014) confirmed that the bound water sites are mostly below $2.5 \mathrm{~nm}$ in diameter. Therefore, the decreasing proportion of bound water sites for all species by TM implies the dehydration and condensation of cellulose (Boonstra and Tjeerdsma 2006). The pores larger than $2.5 \mathrm{~nm}$ are the small void spaces between cellulose chains and microfibrils in cell walls, in which clusters of bound water are condensed (Gezici-Koç et al. 2017). Although the proportion of the small voids $(>2.5 \mathrm{~nm}$ ) increased in modified pine and spruce due to the decrease of bound water sites, their area did not change significantly between modified and unmodified specimens. In contrast, both the proportion and the area of the small voids increased in ash after TM, indicating larger bound water clusters in saturated cell walls.

The number of pores in cell walls increased slightly in all samples except unmodified pine and Thermo-Smodified spruce after weathering, indicating degradation of cell wall structure and better accessibility of water into cell walls. Previous studies reported that weathering causes photodegradation and leaching of cell wall constitutes, particularly lignin (Temiz et al. 2007), which should increase the pore sizes. Surprisingly, the volume of bound water sites and the small voids did not consistently increase in all samples, which might indicate that cell wall swelling is caused by random absorption of water in bound water sites and small voids. However, due to the variation between the specimens before and after weathering, no definite conclusion can be drawn without further examination.

\section{Spatial distribution of free water}

Figure 4 shows the MRI graphs of thermally modified samples measured before and after weathering. The pictures were taken from approximately the middle of the samples along the tangential-radial direction. The signal amplitude in each pixel is directly proportional to the concentration of free water at that position. 
Pine

Thermo S Thermo D
Spruce

Thermo S Thermo D
Ash

Thermo S Thermo $D$
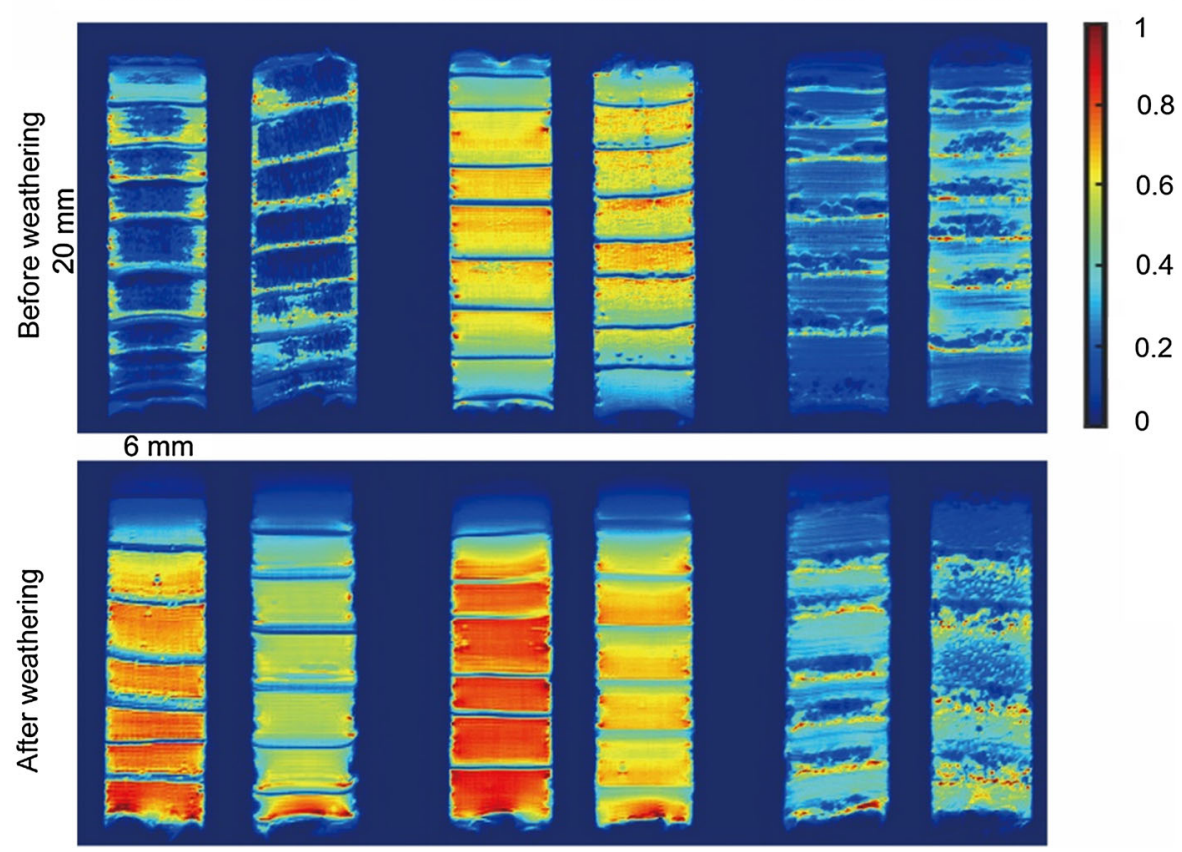

Fig. 4 The MRI of free water distributed in modified wood before and after 2-year natural weathering (the color scale refers to the water signal intensity, red: more water; blue: less water)

Only the signal of free water is visible in the images, because the relaxation time of solid wood and bound water is much shorter than the echo time (13.8 ms) used in MRI experiments (Kekkonen et al. 2014). However, this echo time is longer than part of the $\mathrm{T}_{2}$ of peak $2(5-17 \mathrm{~ms}$, Fig. 2) and peak 5 (8-115 ms) for unmodified controls. Therefore, the free water detected by MRI is smaller than the actual values in those samples. For this reason, the images of unmodified controls are not discussed in this work.

After 1-month immersion under water, the signal arising from earlywood was more intense than that of latewood in both weathered and unweathered samples, because the free water concentration is much higher in the earlywood due to greater lumen volume proportion of the tracheid cells and vessels (Kollmann and Côté 1968).

Consistent with previous research (Kekkonen et al. 2014; Javed et al. 2015), for pine and spruce, severe modification (Thermo D) resulted in better water resistance than milder modification (Thermo $\mathrm{S}$ ). However, the ash sample before weathering demonstrated the opposite behavior, which is an unexplained finding and might be due to sample variation. Weathering increased the water absorption for all samples, but Thermo-D-modified wood showed better performance.

\section{Conclusions}

Weathering caused cell wall degradation and the increased bound water content and FSP in all TMW specimens, indicating degradation of hydrophobic lignin components and a noticeable increase in water accessibility. TM reduces bound water sites in cell walls, and outdoor weathering increases the number of cell wall pores mainly by increasing the number of available bound water sites rather than of interfibrillar voids. An increase in modification intensity then results in an increased water resistance. These findings clarify the processes by which TMW obtains characteristic reduced water accessibility and number of pores that improve its weathering performance compared to unmodified wood. 
Acknowledgments Open access funding provided by Natural Resources Institute Finland (LUKE). The authors wish to present sincere thanks to the International ThermoWood Association and Teollisuusneuvos Heikki Väänänen's Fund for co-funding the project. V-V.Telkki thanks the European Research Council (ERC) under Horizon 2020 (H2020/20182022/ERC Grant Agreement No. 772110), Academy of Finland (Grants \#289649, 294027 and 319216), the Kvantum institute (University of Oulu) and the CA15209 COST action (EURELAX) for financial support. The Laplace inversion program was provided by the late Prof. P. Callaghan.

Open Access This article is licensed under a Creative Commons Attribution 4.0 International License, which permits use, sharing, adaptation, distribution and reproduction in any medium or format, as long as you give appropriate credit to the original author(s) and the source, provide a link to the Creative Commons licence, and indicate if changes were made. The images or other third party material in this article are included in the article's Creative Commons licence, unless indicated otherwise in a credit line to the material. If material is not included in the article's Creative Commons licence and your intended use is not permitted by statutory regulation or exceeds the permitted use, you will need to obtain permission directly from the copyright holder. To view a copy of this licence, visit http://creativecommons.org/licenses/by/4.0/.

\section{References}

Aksnes DW, Kimtys L (2004) 1H and 2H NMR studies of benzene confined in porous solids: melting point depression and pore size distribution. Solid State Nucl Mag 25:146-152. https://doi.org/10.1016/j.ssnmr.2003.03.001

Aksnes DW, Førland K, Kimtys L (2001) Pore size distribution in mesoporous materials as studied by $1 \mathrm{H}$ NMR. Phys Chem Chem Phys 3:3203-3207. https://doi.org/10.1039/ b103228n

Almeida G, Gagné S, Hernández R (2007) A NMR study of water distribution in hardwoods at several equilibrium moisture contents. Wood Sci Technol 41:293-307. https:// doi.org/10.1007/s00226-006-0116-3

Altgen M, Hofmann T, Militz H (2016) Wood moisture content during the thermal modification process affects the improvement in hygroscopicity of Scots pine sapwood. Wood Sci Technol 50:1181-1195. https://doi.org/10.1007/ s00226-016-0845-x

Andersson S, Serimaa R, Väänänen T, Paakkari T, Jämsä S, Viitaniemi P (2005) X-ray scattering studies of thermally modified Scots pine (Pinus sylvestris L.). Holzforschung 59:422-427. https://doi.org/10.1515/HF.2005.069

Boonstra MJ, Tjeerdsma B (2006) Chemical analysis of heat treated softwoods. Holz Roh Werkst 64:204-211. https:// doi.org/10.1007/s00107-005-0078-4

Borrega M, Kärenlampi PP (2011) Cell wall porosity in Norway spruce wood as affected by high temperature drying. Wood Fiber Sci 43:206-214

Brownstein KR (1980) Diffusion as an explanation of observed NMR behavior of water absorbed on wood. J Magn Reson
40:505-510.

https://doi.org/10.1016/0022-

2364(80)90009-8

Brownstein KR, Tarr CE (1979) Importance of Classical Diffusion in NMR Studies of Water in Biological Cells. Phys Rev A 19:2446. https://doi.org/10.1103/PhysRevA.19. 2446

Bucur V (2003) Nondestructive characterization and imaging of wood. Springer, Berlin Heidelberg

Cai C, Antikainen J, Luostarinen K, Mononen K, Heräjärvi H (2018) Wetting-induced changes on the surface of thermally modified Scots pine and Norway spruce wood. Wood Sci Technol 52:1181-1193. https://doi.org/10.1007/ s00226-018-1030-1

Chen CM, Wangaard F (1968) Wettability and the hysteresis effect in the sorption of water vapor by wood. Wood Sci Technol 2:177-187. https://doi.org/10.1007/BF00350907

Chen M, Coasne B, Guyer R, Derome D, Carmeliet J (2018) Role of hydrogen bonding in hysteresis observed in sorption-induced swelling of soft nanoporous polymers. Nature Communications 9:3507. https://doi.org/10.1038/s41467018-05897-9

Ding W, Koubaa A, Chaala A, Belem T, Krause C (2008) Relationship between wood porosity, wood density and methyl methacrylate impregnation rate. Wood Mater Sci Eng 1-2:62-70. https://doi.org/10.1080/ 17480270802607947

Engelund ET, Thygesen LG, Svensson S, Hill CAS (2013) A critical discussion of the physics of wood-water interactions. Wood Sci Technol 47:141-161. https://doi.org/10. 1007/s00226-012-0514-7

Esteves B, Pereira HM (2009) Wood modification by heat treatment: a review. BioResources 4:370-404

Esteves B, Domingos I, Pereira H (2007) Improvement of technological quality of eucalypt wood by heat treatment in air at $170-200^{\circ} \mathrm{C}$. Forest Prod J 57:47-52

Flibotte S, Menon RS, MacKay AL, Hailey JR (1990) Proton magnetic resonance of western red cedar. Wood Fiber Sci 22:362-376

Fredriksson M, Thybring EE (2019) On sorption hysteresis in wood: separating hysteresis in cell wall water and capillary water in the full moisture range. PLoS ONE 14(11):e0225111. https://doi.org/10.1371/journal.pone. 0225111

Fredriksson M, Thygesen LG (2017) The states of water in Norway spruce (Picea abies (L.) Karst.) studied by lowfield nuclear magnetic resonance (LFNMR) relaxometry: assignment of free-water populations based on quantitative wood anatomy. Holzforschung 71:77-90. https://doi.org/ 10.1515/hf-2016-0044

Gao X, Zhuang S, Jin J, Cao P (2015) Bound Water Content and Pore Size Distribution in Swollen Cell Walls Determined by NMR Technology. BioResources 10:8208-8224. https://doi.org/10.15376/biores.10.4.8208-8224

Gezici-Koç Ö, Erich S, Huinink H, Ven L, Adan O (2017) Bound and free water distribution in wood during water uptake and drying as measured by 1D magnetic resonance imaging. Cellulose 24:535-553. https://doi.org/10.1007/ s10570-016-1173-x

Hansen EW, Stöcker M, Schmidt R (1996) Low-Temperature Phase Transition of Water Confined in Mesopores Probed 
by NMR. Influence on Pore Size Distribution. J Phys Chem 100:2195-2200. https://doi.org/10.1021/jp951772y

Hill CAS (2006) Wood modification - chemical, thermal and other processes. Chichester, John Wiley \& Sons, UK

Hill CAS, Forster SC, Farahani MRM, Hale MDC, Ormondroyd GA, Williams GR (2005) An investigation of cell wall micropore blocking as a possible mechanism for the decay resistance of anhydride modified wood. Int Biodeterior Biodegradation 55:69-76. https://doi.org/10.1016/j.ibiod. 2004.07.003

Huang X, Kocaefe D, Kocaefe Y, Boluk Y, Pichette A (2012a) Study of the degradation behavior of heat-treated jack pine (Pinus banksiana) under artificial sunlight irradiation. Polym Degrad Stabil 97:1197-1214. https://doi.org/10. 1016/j.polymdegradstab.2012.03.022

Huang X, Kocaefe D, Kocaefe Y, Boluk Y, Pichette A (2012b) Changes in wettability of heat-treated wood due to artificial weathering. Wood Sci Technol 46:1215-1237. https://doi. org/10.1007/s00226-012-0479-6

Jackson CL, McKenna GB (1990) The Melting Behavior of Organic Materials Confined in Porous Solids. J Chem Phys 93:9002-9011. https://doi.org/10.1063/1.459240

Javed MA, Kekkonen PM, Ahola S, Telkki V-V (2015) Magnetic resonance imaging study of water absorption in thermally modified pine wood. Holzforschung 69:899-907. https://doi.org/10.1515/hf-2014-0183

Kalnins M, Feist W (1993) Increase in wettability of wood with weathering. Forest Prod J 43:55

Kekkonen PM, Ylisassi A, Telkki V-V (2014) Absorption of water in thermally modified pine wood as studied by Nuclear Magnetic Resonance. J Phys Chem C 118:2146-2153. https://doi.org/10.1021/jp411199r

Koddenberg T, Militz H (2018) Morphological imaging and quantification of axial xylem tissue in Fraxinus excelsior L. through X-ray micro-computed tomography. Micron 111:28-35

Kollmann F, Côté WA (1968) Principles of wood science and technology. 1. Solid wood. Springer-Verlag. Berlin, Heidelberg, New York

Labbé N, De Jéso B, Lartigue J, Daudé G, Pétraud M, Ratier M (2006) Time-domain $1 \mathrm{H}$ NMR characterization of the liquid phase in greenwood. Holzforschung 60:265-270. https://doi.org/10.1515/HF.2006.043

Mäkinen H, Jyske T, Saranpaa P (2008) Variation of tracheid length within annual rings of Scots pine and Norway spruce. Holzforschung 62:123-128. https://doi.org/10. 1515/HF.2008.018

Meng X, Foston M, Leisen J, DeMarini J, Wyman C, Ragauskas A (2013) Determination of porosity of lignocellulosic biomass before and after pretreatment by using Simons' stain and NMR techniques. Bioresource Technol 144:467-476. https://doi.org/10.1016/j.biortech.2013.06. 091

Menon RS, MaCkay AL, Hailey JRT, Bloom M, Burgess AE, Swanson JS (1987) An NMR determination of the physiological water distribution in wood during drying. J Appl Polym Sci 33:1141-1155. https://doi.org/10.1002/app. 1987.070330408

Menon RS, Mackay AL, Flibotte S, Hailey JRT (1989) Quantitative separation of NMR images of water in wood on the basis of T2. J Magn Reson 82:205-210. https://doi.org/10. 1016/0022-2364(89)90184-4

Nakatani T, Ishimaru Y, Iida I, Furuta Y (2008) Micropore structure of wood: change in micropore structure accompanied by delignification. Wood Sci 54:252-255. https:// doi.org/10.1007/s10086-007-0931-7

Park S, Venditti RA, Jameel H, Pawlak J (2006) Changes in pore size distribution during the drying of cellulose fibers as measured by differential scanning calorimetry. Carbohyd Polym 66:97-103. https://doi.org/10.1016/j.carbpol.2006. 02.026

Peng L, Wang D, Fu F, Song B (2015) Analysis of wood pore characteristics with mercury intrusion porosimetry and X-ray micro-computed tomography. Wood Research 60:857-864

Petrov OV, Furó I (2006) Curvature-Dependent Metastability of the Solid Phase and the Freezing-Melting Hysteresis in Pores. Phys Rev E 73:No. 011608. https://doi.org/10.1103/ physreve.73.011608

Petrov OV, Furó I (2009) NMR cryoporometry: principles, applications and potential. Nuclear Magnetic Resonance Spectroscopy 54:97-122. https://doi.org/10.1016/j.pnmrs. 2008.06.001

Provencher SW (1982) A constrained regularization method for inverting data represented by linear algebraic or integral equations. Comput Phys Commun 27:213-227. https://doi. org/10.1016/0010-4655(82)90173-4

Riggin MT, Sharp AR, Kaiser R, Schneider MH (1979) Transverse NMR relaxation of water in wood. J Appl Polym Sci 23(11):3147-3154. https://doi.org/10.1002/app.1979. 070231101

Roles S, Elsen J, Carmeliet J, Hens H (2001) Characterization of pore structure by combining mercury porosimetry and micrography. Mater Struct 34:76-82. https://doi.org/10. 1007/BF02481555

Song YQ, Venkataramanan L, Hürlimann MD, Flaum M, Frulla $\mathrm{P}$, Straley C (2002) $\mathrm{T}_{1}-\mathrm{T}_{2}$ correlation spectra obtained using a fast two-dimensional Laplace inversion. J Magn Reson 154:261-268. https://doi.org/10.1006/jmre.2001. 2474

Stone J (1964) The porous structure of wood and fibers. Pulp Paper Mag Can 65(1):T3-T13

Stone JE, Scallan AM (1967) Effect of component removal upon porous structure of cell wall of wood-2. Swelling in water and fiber saturation point. Tappi 50:496-501

Strange JH, Rahman M, Smith EG (1993) Characterization of Porous Solids by NMR. Phys Rev Lett 71:3589-3591. https://doi.org/10.1103/PhysRevLett.71.3589

Telkki V-V (2018) Hyperpolarized Laplace NMR. Magn Reson Chem 56:619-632. https://doi.org/10.1002/mrc.4722

Telkki V-V, Yliniemi M, Jokisaari J (2013) Moisture in softwoods: fiber saturation point, hydroxyl site content, and the amount of micropores as determined from NMR relaxation time distributions. Holzforschung 67:291-300. https://doi. org/10.1515/hf-2012-0057

Temiz A, Terziev N, Eikenes M, Hafren J (2007) Effect of accelerated weathering on surface chemistry of modified wood. Appl Surf Sci 253:5355-5362. https://doi.org/10. 1016/j.apsusc.2006.12.005

Tjeerdsma BF, Militz H (2005) Chemical changes in hydrothermal treated wood: fTIR analysis of combined 
hydrothermal and dry heat treated wood. Holz als Roh und Werkst off 63:102-111. https://doi.org/10.1007/s00107004-0532-8

Tomak ED, Ustaomer D, Ermeydan MA, Yildiz S (2018) An investigation of surface properties of thermally modified wood during natural weathering for 48 months. Measurement 127:187-197. https://doi.org/10.1016/j. measurement.2018.05.102

Viitaniemi P, Jämsä S, Ek P, Viitanen H (1997) Method for improving biodegradation resistance and dimensional stability of cellulosic products. U.S. Pat, US, p 5678324

Welzbacher CR, Rassam G, Talaei A, Brischke C (2011) Microstructure, strength and structural integrity of heattreated beech and spruce wood. Wood Mater Sci Eng 6:219-227. https://doi.org/10.1080/17480272.2011. 622411

Williams RS (2005) Weathering of wood. In: Rowell RM (ed) Handbook of Wood Chemistry and Wood Composites. CRC Press, Boca Raton, pp 142-185
Yin J, Song K, Lu Y, Zhao G, Yin Y (2015) Comparison of changes in micropores and mesopores in the wood cell walls of sapwood and heartwood. Wood Sci Technol 49:987-1001. https://doi.org/10.1007/s00226-015-0741-9

Zauer M, Pfriem A, Wagenführ A (2013) Toward improved understanding of the cell-wall density and porosity of wood determined by gas pycnometry. Wood Sci Technol 47:1197-1211. https://doi.org/10.1007/s00226-013-05681

Zauer M, Kretzschmar J, Grossmann L, Pfriem A, Wagenfuhr A (2014) Analysis of the pore-size distribution and fiber saturation point of native and thermally modified wood using differential scanning calorimetry. Wood Sci Technol 48:177-193. https://doi.org/10.1007/s00226-013-0597-9

Publisher's Note Springer Nature remains neutral with regard to jurisdictional claims in published maps and institutional affiliations. 